UDC 613.646: 622.276

DOI: 10.21668/health.risk/2019.4.09.eng

\title{
RISK FACTORS CAUSING HEALTH DISORDERS AMONG WORKERS INVOLVED IN OIL EXTRACTION AND PERFORMING THEIR WORKING TASKS OUTDOORS DURING A COLD SEASON
}

\author{
E.M. Polyakova ${ }^{1,2}$, A.V. Mel'tser ${ }^{1}$, V.P. Chashchin ${ }^{1}$ \\ ${ }^{1}$ North-Western State Medical University named after I.I. Mechnikov, 41 Kirochnaya avenue, Saint Petersburg, \\ 195067, Russian Federation \\ ${ }^{2}$ North-West Scientific Center for Hygiene and Public Health, Russia, 191036, Saint Petersburg, 2 Sovetskaya Str., 4
}

\begin{abstract}
The research focuses on a vital issue related to preserving health of workers who perform their working tasks outdoors in regions with cold climate.

Our research goal was to examine influence exerted by working conditions and working experience length on prevalence of chronic diseases and other health disorders among workers who performed their working tasks outdoors during a cold season.

We accomplished a cross (one-moment) epidemiologic study aimed at assessing adverse impacts exerted by weather and climatic factors on workers who performed their working tasks on open grounds in regions with cold climate. We conducted hygienic assessment of working conditions for 1.647 workers employed at oil-extracting enterprise in Nizhnevartovsk and analyzed results obtained during their regular medical check-ups.

We analyzed average number of diseases per 1 worker; it varied from $(0.45 \pm 0.06)$ among workers dealing with electrogas welding to $(0.27 \pm 0.022)$ among compressor unit operators. Each additional 5 years of working experience resulted in an ascending trend for a number of detected diseases per 1 worker $(p=0.0015)$.

We also revealed that workers who maintained oil-extracting machinery ran the greatest health risks as they had to spend the greatest amount of time outdoors (on average, 27 hours out of 40 hours per 1 working week) during a cold season. Besides, our research showed that exposure to cold potentiated adverse impacts exerted by other occupation factors on workers' health. Thus, given the same amount of time spent outdoors during a cold season for different occupational groups, welders ran the greatest risks of circulatory system diseases $(A R=2.0)$, ear and mastoid diseases $(A R=5.0)$, digestive organs diseases $(A R=2.2)$ due to the air at their working places being contaminated with welding aerosol.

When working tasks are performed outdoors in regions with cold climate, it leads to elevated risks of chronic health disorders that occur due to long-term occupational exposure to uncontrollable meteorological factors and simultaneous air contamination with welding aerosols.

Key words: working conditions, oil-industry workers, adverse working conditions, work on open grounds, cold, workers' health, cold injuries, cold stress, cold and carbohydrate metabolism.
\end{abstract}

Oil extraction plays the leading role in the economy of northern regions in West $\mathrm{Si}$ beria. A significant number of employable people work in the branch. Technologies that are applied at oil-extracting enterprises are developing rapidly; still, s lot of workers employed at such enterprises in West Siberia work in adverse working conditions. A specific weight of workers who were employed at fuel and energy resources extraction (including oil and gas) and performed their work tasks in adverse or hazardous conditions increased from $44.1 \%$ in 2012 to $54.7 \%$ in 2018 [1]. There are several risk factors that cause general and occupational diseases: they are overall and local vibration, noise, adverse chemicals and aerosols, physical strain, work in forced and uncomfortable postures, as well

(C) Polyakova E.M., Mel'tser A.V., Chashchin V.P., 2019

Ekaterina M. Polyakova - Postgraduate Student at the Department for Preventive Medicine and Health Protection (e-mail: USTIMENKOEKATERINA_2009@mail.ru; tel.: +7 (812) 303-50-00; ORCID: https://orcid.org/0000-0003-3493-4592).

Alexander V. Mel'tser - Doctor of Medical Sciences, Vice-Rector responsible for Regional public Healthcare Development and Medical Prevention, Head of the Department for Preventive Medicine and Health Protection (e-mail: Aleksandr.Meltcer@szgmu.ru; tel.: +7 (812) 303-50-00; ORCID: https://orcid.org/0000-0003-4186-457).

Valeriy P. Chashhin - Honored Scientist of the Russian Federation, Doctor of Medical Sciences, Professor, Head of the Research Laboratory dealing with Complex Problems of Hygiene and Epidemiology (e-mail: valerych05@mail.ru; tel.: +7 (921) 958-88-85; ORCID: https://orcid.org/0000-0002-2600-0522). 
as some other factors related to working environment or work processes. And we should note that these adverse occupational factors exert their influence in specific natural and climatic conditions existing in the Polar Regions. Cold season is very long there and air temperatures are low [2-4]. An enterprise which we examined in the present work was located in an area where average long-term temperature was equal to $-24,4{ }^{\circ} \mathrm{C}$ during three coldest months, and snow cover didn't melt for 200-210 days ${ }^{1}$. In 2018 workers employed at mining and extracting enterprises had the greatest specific weight of occupational diseases, $47.59 \%$ of all the first registered morbidity cases. In 2018 occupational morbidity per 10 thousand workers registered at mining enterprises held the first rank place among all types of economic activities; it was equal to $25.01^{2}$.

We examined impacts exerted by working conditions existing on open-air facilities in the Polar Regions on health of workers employed by an oil-extracting company; those workers had to spend a lot of time outdoors during their working week.

Our research goal was to examine influence exerted by cold factor on workers employed by an oil-extracting enterprise when they had to work outdoors in cold season and were exposed to adverse occupational factors related to specific working environment.

Data and methods. We examined influence exerted by working conditions in cold season on health of workers employed by an oil-extracting enterprise depending on a period of time they had to spend outdoors during a working shift. We analyzed structure and intensity of effects produced by adverse occupational factors and results obtained during periodical medical check-ups of 1,674 workers employed by "Samotlorneftegaz" public company (located in Nizhnevartovsk, the Khanty-
Mansi Autonomous Area). Basing on a performed time study, we divided all workers into three groups with different amount of time spent outdoors in cold season and taking into account exposure to adverse occupational factors. The first group included 344 people (about $30 \%$ of a working shift spent outdoors); the second one was made up of 647 people (about $50 \%$ of a working shift spent outdoors); there were 689 people in the third group (60-75\% of a working shift spent outdoors).

We assessed impacts exerted by working experience on workers' health after all the examined workers had been divided into four groups: with working experience not exceeding 5 years $(n=796)$; $6-10$ years $(n=238)$; $11-15$ years $(n=201)$; and longer than $16-20$ years $(n=441)$. When assessing working conditions, we took into account labor hardness and intensity, microclimate at workplaces, and exposure to physical and chemical factors [5-8]. We performed statistical analysis with Statistica 12.0 for Windows; we determined Student's t-test for independent samplings, goodness-of-fit test $\chi^{2}$, attributable risk (AR), and Pearson's linear correlation quotient $(r)$. Numeric data were given as a mean value and its standard error $(M \pm m)$. Discrepancies were considered to be significant at $p<0.05$. Data on working conditions were assessed as per reports of special assessment of working conditions accomplished in 2016 at workplaces where workers from the selected occupational groups performed their work tasks as well as basing on industrial control protocols issued in 2010-2018. Prevalence of diseases among workers employed by "Samotlorneftegaz" public company was assessed basing on results of periodical medical check-ups collected in 2017-2018 (Appendix No. 1).

Results and discussion. We assessed working conditions and revealed that noise and

\footnotetext{
${ }^{1}$ CSaR 23-01-99. Construction climatology (with Amendment No. 1). Construction standards and rules in the Russian Federation. Construction climatology. Electronic fund for legal and reference documentation, 2000. Available at: http://docs.cntd.ru/document/1200004395 (date of visit June 19, 2019).

${ }^{2}$ On sanitary-epidemiologic welfare of the population in the Russian Federation in 2018. The State report. The Federal Service for Surveillance over Consumer Rights Protection and Human Well-being, 2019. Available at: https://rospotrebnadzor.ru/documents/ (date of visit June 19, 2019).
} 
overall vibration at them exceeded acceptable levels, and certain adverse chemicals were detected in working area air in quantities higher than hygienic standards. Overall vibration exceeded hygienic standards (working conditions belonging to 3.1 hazard category) for operators who handled pumping units (PU) and compressor units (CU) (workers from the $1^{\text {st }}$ group); oil-extracting devices handled by those workers included units for pumping working substance into a bed, vacuum compressors, units for pumping trapped oil, deposit water, outer drainage, storm drainage, and dehydrating and desalting units (DDU). Adverse chemical factors included substances belonging to 1-4 hazard categories (oil and its components, dihydrosulfate, sulfur dioxide, carbon oxide, nitrogen oxide, and ozone). Maximum manganese concentrations that existed at workplaces of repairmen were up to 1.17 times higher than MPC (working conditions belonging to 3.1 hazard category) with maximum single MPC being equal to $0.6 \mathrm{mg} / \mathrm{m}^{3}$. Electrogas welders were also exposed to increased manganese concentrations that exceeded MPC. When performing their work tasks, welders were exposed to ozone concentrations that were 1.13 times higher than MPC. Technological processes applied in oil extraction involved working in forced and uncomfortable postures and a worker had to move a lot during a working shift sometimes covering a distance equal to $8.4 \mathrm{~km}$. Overall, working conditions for workers from the $1^{\text {st }}$ group were the most hazardous (3.3 category) than for those from the $2^{\text {nd }}$ and the $3^{\text {rd }}$ ones (3.2 category) (Table 1$)$.

We accomplished a time study of work processes in the examined occupational groups basing on observation checklists or working day profiles; it allowed us to determine that workers from the $3^{\text {rd }}$ group had to spend the longest period of time outdoors or in cold rooms during a 40-hour working week among all the examined groups ( $27 \pm 0.23$ hours).

We analyzed results obtained via periodical medical examinations of workers from the selected occupational groups in 2017-2018. There were no authentic differences among workers as per their age; we revealed a distinct correlation between an average number of detected diseases per one worker and an amount of time workers had to spend outdoors in cold season during a 40-hour working week. Thus, there was a strong direct correlation between periods of time spent outdoors by workers from the $3^{\text {rd }}$ group and a number of diseases per one worker $(0.37 \pm 0.02)$; it was the strongest among all the examined groups $(r=0.74)$. Also, a fraction of practically healthy people was authentically lower $(70.5 \%)$ than in the $2^{\text {nd }}$ group $\left(\chi^{2}=11.422 ; p=<0001\right)$ (Table 2).

We examined morbidity among workers from the examined occupational groups as per their age and sex depending on their working experience, a number of diseases per one worker, and average amount of time spent outdoors in cold season.

Circulatory system diseases were the most frequently detected in all three examined

Table 1

Assessment of working conditions for workers from the examined occupational groups employed at an oil-extracting enterprise

\begin{tabular}{|l|c|c|c|}
\hline \multicolumn{1}{|c|}{ Parameter } & $\begin{array}{c}\text { Group 1 } \\
\text { CU operators } \\
\text { and PU operators }\end{array}$ & $\begin{array}{c}\text { Group 2 } \\
\text { DDU operators }\end{array}$ & $\begin{array}{c}\text { Group 3 } \\
\text { Repairmen / } \\
\text { Elector-gas welders }\end{array}$ \\
\hline Chemical factors & 2.0 & 2.0 & 3.1 \\
\hline Noise & 3.3 & 3.2 & 3.2 \\
\hline Overall vibration & 3.1 & 2.0 & 2.0 \\
\hline Labor hardness & 2.0 & 3.1 & 3.1 \\
\hline Working conditions category & 3.3 & 3.2 & 3.2 \\
\hline
\end{tabular}


Table 2

Sex and age characteristics of the examined occupational groups depending on work experience, a number of diseases per one worker, and average amount of time spent outdoor in cold season

\begin{tabular}{|l|c|c|c|c|}
\hline \multicolumn{1}{|c|}{ Parameter } & $\begin{array}{c}\text { Group 1 } \\
\text { CU operators } \\
\text { and PU operators }\end{array}$ & $\begin{array}{c}\text { Group 2 } \\
\text { DDU operators }\end{array}$ & $\begin{array}{c}\text { Group 3 } \\
\text { Repairmen / } \\
\text { Elector-gas welders }\end{array}$ & Total \\
\hline Sex, men & $299(87 \%)$ & $352(54.92 \%)$ & $688(99.85 \%)$ & $1,339(80 \%)$ \\
\hline Sex, women & $45(13 \%)$ & $289(45.08 \%)$ & $1(0.15 \%)$ & $335(20 \%)$ \\
\hline Average age, years & $42.89 \pm 0.55$ & $40.16 \pm 0.4$ & $40.42 \pm 0.41$ & $40.83 \pm 0.26$ \\
\hline Average work experience & $10.32 \pm 0.37$ & $9.88 \pm 0.27$ & $7.65 \pm 0.29$ & $9.05 \pm 0.16$ \\
\hline $\begin{array}{l}\text { AS number of practically } \\
\text { healthy workers }\end{array}$ & $252(73.3 \%)$ & $504(78.6 \%)$ & $486(70.5 \%)$ & $1,242(74.19 \%)$ \\
\hline $\begin{array}{l}\text { An average number of } \\
\text { diseases per one workers }\end{array}$ & $0.33 \pm 0.034$ & $0.27 \pm 0.022$ & $0.37 \pm 0.02$ & $0.32 \pm 0.014$ \\
\hline $\begin{array}{l}\text { Average amount of time } \\
\text { spent outdoors in cold } \\
\text { season during a 40-hour } \\
\text { working week }\end{array}$ & $14.1 \pm 0.013$ & $24.5 \pm 0.07$ & $27 \pm 0.23$ & $23.4 \pm 0.15$ \\
\hline
\end{tabular}

groups and held the $1^{\text {st }}$ rank place accounting for $24.8 \%$; the $2^{\text {nd }}$ rank place belonged to endocrine system diseases $(18 \%)$. The $3^{\text {rd }}$ rank place was taken by symptoms, signs, and deviations from physiological standards revealed via clinical and laboratory research, namely, deviations in tolerance to dextrose $(17.4 \%)$. There were no statistically significant discrepancies between three groups regarding these three rank places. Ear and mastoid diseases accounted for $15.6 \%$ in morbidity structure in all three groups of workers employed by "Samotlorneftegaz" public company and it was the $4^{\text {th }}$ rank place.

Overall, prevalence of diseases was the same in all three occupational groups, the $1^{\text {st }}$ rank place taken by cardiovascular diseases; the $2^{\text {nd }}$ rank place in the $1^{\text {st }}$ and $2^{\text {nd }}$ group taken by endocrine diseases, and by ear and mastoid diseases in the $3^{\text {rd }}$ group; the $3^{\text {rd }}$ rank place belonged to deviations in tolerance to dextrose in all three occupational groups.

Prevalence of ear and mastoid diseases per 100 workers was 1.875 and 2.8 times authentically higher in the $3^{\text {rd }}$ group that in the $1^{\text {st }}$ and $2^{\text {nd }}$ one accordingly $\left(\chi^{2}=17.61, d f=2\right.$, $p<0.001)$. Digestive organs diseases held the $5^{\text {th }}$ rank place and their prevalence in the $3^{\text {rd }}$ group $(4.4 \%)$ was authentically higher than in the $1^{\text {st }}$ one $(3.8 \%)$ and in the $2^{\text {nd }}$ one $(1.2 \%)$ accordingly $\left(\chi^{2}=11.633, d f=2, p=0.003\right)$.

We revealed substantial discrepancies in prevalence of blood and blood-making organs diseases between the examined groups; thus, morbidity in the $2^{\text {nd }}$ group $(8.2 \%)$ was authentically higher than in the $1^{\text {st }}(6.9 \%)$ and the $3^{\text {rd }}$ one $(1.6 \%)$ accordingly $\left(\chi^{2}=7.274, d f=2\right.$, $p=0,027)$.

Some chronic diseases tended to prevail in workers from the $3^{\text {rd }}$ occupational group and were the most frequent among them, in particular, circulatory organs diseases, ear and mastoid diseases, digestive organs diseases, skin and subcutaneous tissues diseases, as well as symptoms, signs, and deviations from physiological standards revealed via clinical and laboratory research. Those diseases accounted for the biggest part of all diseases detected among workers from the examined occupational groups (Table 3 ).

We calculated attributable risk and revealed that influence exerted by longer overall exposure to cold during a working week was accompanied with excessive morbidity ${ }^{3}$ with

\footnotetext{
${ }^{3}$ Metody obrabotki informatsii [Information processing techniques]. In: A.G. Sysa, R.A. Dudinskaya. Minsk, IVTs Minfina Publ., 2018, 20 p.
} 
Table 3

Prevalence of diseases among workers employed at oil-extracting enterprise that had to work in different working conditions (number of cases per 100 workers) as per results of periodical medical examinations

\begin{tabular}{|l|c|c|c|c|}
\hline \multicolumn{1}{|c|}{ Disease category as per ICD-10 } & Group 1 & Group 2 & Group 3 & Total \\
\hline Diseases of the circulatory system & $8.4 \pm 1.49$ & $6.7 \pm 0.98$ & $8.7 \pm 1.07$ & $7.9 \pm 0.66$ \\
\hline Endocrine, nutritional, and metabolic diseases & $6.1 \pm 0.52$ & $6.4 \pm 0.97$ & $4.9 \pm 0.82$ & $5.7 \pm 0.57$ \\
\hline $\begin{array}{l}\text { Symptoms, signs and abnormal clinical and } \\
\text { laboratory findings, not elsewhere classified }\end{array}$ & $5.5 \pm 1.2$ & $4.2 \pm 0.79$ & $6.8 \pm 0.96$ & $5.5 \pm 0.55$ \\
\hline Diseases of the ear and mastoid process & $4 \pm 1.06$ & $2.5 \pm 0.55$ & $7.5 \pm 1$ & $4.9 \pm 0.53$ \\
\hline Diseases of the digestive system & $3.8 \pm 1.03$ & $1.2 \pm 0.43$ & $4.4 \pm 0.78$ & $3 \pm 0.42$ \\
\hline $\begin{array}{l}\text { Diseases of the blood and blood-forming organs } \\
\text { and certain disorders involving the immune } \\
\text { mechanism }\end{array}$ & $2.3 \pm 0.8$ & $2.2 \pm 0.58$ & $0.6 \pm 0.29$ & $1.6 \pm 0.3$ \\
\hline Diseases of the genitourinary system & $2 \pm 0.75$ & $1.6 \pm 0.49$ & $0.9 \pm 0.36$ & $1.4 \pm 0.29$ \\
\hline Diseases of the musculoskeletal system & $1.5 \pm 0.65$ & $0.8 \pm 0.36$ & $1 \pm 0.38$ & $1 \pm 0.37$ \\
\hline Diseases of the skin and subcutaneous tissue & 0 & $0.3 \pm 0.22$ & $0.7 \pm 0.32$ & $0.4 \pm 0.15$ \\
\hline Other diseases & 0 & $0.5 \pm 0.28$ & $0.3 \pm 0.2$ & $0.3 \pm 0.13$ \\
\hline
\end{tabular}

ear and mastoid diseases $(\mathrm{AR}=3)$ as well as more frequent deviations in tolerance to dextrose $(\mathrm{AR}=1.3)$. Therefore, excess annual frequency of ear and mastoid diseases amounted to 2.4 cases per 100 workers in the occupational group who had to spend the longest period of time outdoors. Excess annual frequency of deviations in tolerance to dextrose amounted to 1 case per 100 workers in the occupational group who had to spend the longest period of time outdoors.

Long periods of time spent outdoors in cold season combined with exposure to adverse chemicals detected in working area air lead to a substantial increase in morbidity with circulatory system diseases ( $\mathrm{AR}=2.0)$, ear and mastoid diseases $(\mathrm{AR}=5.0)$, digestive organs diseases $(A R=2.2)$ as well as to an increase in number of workers with deviations in tolerance to dextrose $(\mathrm{AR}=2.6)$. Discrepancies in morbidity detected among exposed and non-exposed workers as per overall vibration were determined by combined exposure to cold and overall vibration which substantially increased prevalence of digestive organs diseases $(\mathrm{AR}=2.6)$, circulatory system diseases $(\mathrm{AR}=1.7)$, and ear and mastoid diseases $(\mathrm{AR}=1.5)$.
We examined influence exerted by work experience on health of workers employed at oil extraction and revealed that a number of practically healthy people was the highest among those with their work experience not exceeding 5 years $(76.7 \%)$ against workers with longer work experience. Circulatory system diseases prevailed among detected health disorders including primary hypertension with predominant damage to the heart with (congestive) heart failure (Table 4). Still, we didn't detect any growth in morbidity with circulatory system diseases among workers with longer work experience and there were no statistically significant discrepancies as per this parameter between groups of workers with different work experience. It is probably due to a so called "healthy worker" effect when there is a trend for a decrease in number of workers who work in harmful working conditions and suffer from chronic diseases ${ }^{4}$ $[9,10]$. As a rule, nosologies that predominantly occur at an older age, including cardiovascular pathologies, characterize "healthy worker" effect during later periods of a person's work experience.

\footnotetext{
${ }^{4}$ Rossiiskaya entsiklopediya po meditsine truda [The Russian encyclopedia on occupational medicine]. Rossiiskaya akademiya meditsinskikh nauk. In: N.F. Izmerov. Moscow, Meditsina Publ., 2005, 656 p. (in Russian).
} 
Table 4

Prevalence of diseases among workers from the examined occupational groups as per different work experience

\begin{tabular}{|l|c|c|c|c|c|c|c|}
\hline \multicolumn{1}{|c|}{ Clinical parameters } & \multicolumn{5}{|c|}{ Work experience / } \\
\cline { 2 - 7 } & $\begin{array}{c}<5 \text { years } \\
(n=866)\end{array}$ & $\begin{array}{c}6-10 \text { years } \\
(n=212)\end{array}$ & $\begin{array}{c}11-15 \text { years } \\
(n=164)\end{array}$ & $\begin{array}{c}16-20 \text { years } \\
(n=432)\end{array}$ & $\begin{array}{c}>20 \text { years } \\
(n=0)\end{array}$ & $\begin{array}{c}\text { Total } \\
(n=1,674)\end{array}$ \\
\hline $\begin{array}{l}\text { Prevalence of diseases per } \\
\text { 100 people }\end{array}$ & 27.7 & 22.6 & 34.15 & 43.75 & 0 & 31.8 \\
\hline $\begin{array}{l}\text { Number of diseases } \\
\text { in 1 worker, cases }\end{array}$ & $0.29 \pm 0.019$ & $0.24 \pm 0.037$ & $0.34 \pm 0.049$ & $0.44 \pm 0.03$ & 0 & $0.32 \pm 0.014$ \\
\hline Practically healthy people, \% & 76.7 & 80.7 & 73.2 & 66.4 & 0 & $1,244 / 74.3$ \\
\hline Age, years & $37.13 \pm 0.35$ & $37.63 \pm 0.59$ & $42.31 \pm 0.66$ & $49.26 \pm 0.32$ & 0 & $40.83 \pm 0.26$ \\
\hline \multicolumn{1}{|c|}{ Diseases category as per ICD-10/\% in morbidity structure } \\
\hline $\begin{array}{l}\text { Diseases of the circulatory } \\
\text { system }\end{array}$ & $25.0 \pm 1.5$ & $18.7 \pm 2.7$ & $25 \pm 3.4$ & $25.9 \pm 2.1$ & 0 & $24.8 \pm 1.05$ \\
\hline $\begin{array}{l}\text { Endocrine, nutritional, and } \\
\text { metabolic diseases }\end{array}$ & $14.2 \pm 1.2$ & $25.0 \pm 2.9$ & $23.2 \pm 3.2$ & $19.6 \pm 1.9$ & 0 & $18 \pm 0.9$ \\
\hline $\begin{array}{l}\text { Symptoms, signs and abnormal } \\
\text { clinical and laboratory findings, } \\
\text { not elsewhere classified }\end{array}$ & $15.4 \pm 1.2$ & $16.7 \pm 2.6$ & $19.6 \pm 3$ & $19.6 \pm 1.9$ & 0 & $17.4 \pm 0.9$ \\
\hline $\begin{array}{l}\text { Diseases of the ear and mas- } \\
\text { toid process }\end{array}$ & $14.6 \pm 1.2$ & $14.6 \pm 2.4$ & $23.2 \pm 3.3$ & $14.8 \pm 1.7$ & 0 & $15.6 \pm 0.9$ \\
\hline Diseases of the digestive system & $15.8 \pm 1.2$ & $10.4 \pm 2$ & 0 & $4.2 \pm 0.96$ & 0 & $9.6 \pm 0.7$ \\
\hline $\begin{array}{l}\text { Diseases of the blood and } \\
\text { blood-forming organs and } \\
\text { certain disorders involving } \\
\text { the immune mechanism }\end{array}$ & $4.2 \pm 0.7$ & $4.2 \pm 1.4$ & $3.6 \pm 1.45$ & $6.3 \pm 1.2$ & 0 & $4.9 \pm 0.5$ \\
\hline $\begin{array}{l}\text { Diseases of the genitourinary } \\
\text { system }\end{array}$ & $4.6 \pm 0.7$ & $6.26 \pm 1.7$ & 0 & $4.8 \pm 1.03$ & 0 & $4.3 \pm 0.5$ \\
\hline $\begin{array}{l}\text { Diseases of the musculo- } \\
\text { skeletal system }\end{array}$ & $3.3 \pm 0.6$ & $1.2 \pm 0.75$ & $1.8 \pm 1.04$ & $3.7 \pm 0.9$ & 0 & $3.2 \pm 0.4$ \\
\hline $\begin{array}{l}\text { Diseases of the skin and } \\
\text { subcutaneous tissue }\end{array}$ & $1.7 \pm 0.4$ & 0 & $3.6 \pm 1.45$ & $0.5 \pm 0.3$ & 0 & $1.3 \pm 0.28$ \\
\hline Other diseases & $1,25 \pm 0.38$ & $1,2 \pm 0,75$ & 0 & $0,5 \pm 0.3$ & 0 & $0,9 \pm 0.23$ \\
\hline
\end{tabular}

We detected statistically significant increase in prevalence of all the diseases per 100 workers among those with their work experience being equal to 16-20 years against workers with short work experience $\left(\chi^{2}=15.806\right.$, $d f=1, p<0.001)$. We also detected an authentic fall in number of people without any diagnosed diseases / practically healthy people among workers with 16-20 years of work experience against workers with short work experience $\left(\chi^{2}=15.806, d f=1, p<0.001\right)$.

As work experience grew, there appeared a growing trend in average number of detected diseases per 1 worker $(p=0.0015)$. Endocrine diseases took the $1^{\text {st }}$ rank place in workers with
6-10 years of work experience, and their share increased considerably from $14.2 \%$ to $25 \%$; however, as work experience grew by each 5 years, there was a substantial decrease in morbidity with such diseases $(p=0.007)$. Prevalence of symptoms, signs and abnormal clinical and laboratory findings (deviations in tolerance to dextrose) persistently took the $3^{\text {rd }}$ rank place in morbidity among workers and as their work experience reached 11-15 years it leveled off (19.6\%). According to scientific research results there is a statistically significant increase in dextrose concentration in blood under exposure to extreme cold $[11,12]$. It can be caused by substantial activation of 
thermogenesis and peculiarities of nutrition in cold season that result in elevated concentrations of glycation end products in tissues and increase risks of II type pancreatic diabetes.

As work experience reached 11-15 years, there was a significant growth in prevalence of ear and mastoid diseases, from $14.6 \%$ to $23.2 \%(p=0.028)$ (Table 4$)$.

We detected a weak direct correlation between work experience and an average number of diseases $(r=+0.091)$. There was also a correlation between work experience and prevalence of the most frequent diseases that took the $1^{\text {st }}, 2^{\text {nd }}$, and $3^{\text {rd }}$ rank places such as cardiovascular diseases $(r=+0.0564)$, and endocrine system diseases $(r=+0.0691)$, as well as deviations in tolerance to dextrose $(r=+0.08)$ (a correlation is direct and weak).

Diseases in the digestive organs tended to become less prevalent as work experience grew longer. Circulatory diseases were at the same level regardless of work experience becoming longer. As for other diseases, such as endocrine system diseases, ear and mastoid diseases, blood and blood-making organs diseases, and musculoskeletal system diseases, there was a stable growth in their prevalence, although not the same for all the nosologies. Prevalence of arterial hypertension with predominant damage to heart and (congestive) heart failure grew by 1.4 times against its initial level when work experience reached 16-20 years $[13,14]$; insulin-independent pancreatic diabetes, by 2.75 times; hypercholesterolemia, by 1.8 times; deviations in tolerance to dextrose, by 2.2 times; iron-deficiency anemia, 3.5 times; two-sided conductive deafness, by 2 times. When work experience exceeded 20 years, prevalence of insulin-independent pancreatic diabetes grew by 3 times; irondeficiency anemia, by 4 times; prevalence of two-sided conductive deafness amounted to 7 people per 100 workers.

\section{Conclusions}

1. Our research on influence exerted by working conditions on workers' health revealed that a period of time spent outdoors in cold season was a significant risk factor that could cause health disorders among workers from the $3^{\text {rd }}$ occupational group employed by "Samotlorneftegaz" public company.

2. Such health disorders as ear and mastoid diseases as well as deviations in tolerance to dextrose were the most frequent among workers who had to spend the longest period of time outdoors or in cold rooms in cold season; prevalence of those disorders was the greatest among them.

3 . There was a growth in prevalence of ear and mastoid diseases among workers who repaired and maintained drilling and oil-extracting equipment such as repairmen and electro-gas welders; this growth was due to long-term exposure to adverse uncontrollable occupational factors such as cold and simultaneous contamination with weldingproduced aerosols.

4. Non-occupational two-sided conductive hearing loss was the most prevailing pathology among ear and mastoid diseases; it was widely spread among workers who had to spend the longest period of time outdoors. This pathology was usually caused by complications after acute otitis media or by chronic otitis media $[15,16]$.

5. High frequency of tolerance to dextrose deviating from physiological standards among workers who had to perform their work tasks outdoors in cold season was associated with a growth in insulin-independent pancreatic diabetes occurring in workers with longer work experience; it grew by 3 times when work experience exceeded 16-20 years. Disorders in tolerance to dextrose are compensated when adverse cold factor is removed and are corrected by healthy nutrition in case test results deviate from physiological standards.

6 . When workers are simultaneously exposed to cold weather and contamination of working area air with adverse chemicals and welding-produced aerosols, it leads to a significant increase in prevalence of circulatory diseases $(A R=2)$, ear and mastoid diseases $(A R=5)$, and digestive organs diseases $(\mathrm{AR}=2.2)$, and it is consistent with results of several previous works [17-20].

Therefore, our research results indicate it is necessary to develop a specific recovery and 
health-improving program for workers from senior age groups who have to spend a lot of time outdoors in cold season in areas with cold climate. This program should be oriented at primary and secondary prevention of health disorders that are very likely to occur among workers from such occupational groups; first of all, it should cover II type pancreatic diabetes, ear and mastoid diseases, and circulatory diseases. Also it is necessary to organize groups of workers who run high occupational risks of cold-induced diseases and therefore should undergo regular medical check-ups.

Financing. The study did not have any financial support.

Conflict of interests. Authors declare there is no any conflict of interests.

\section{References}

1. Usloviya truda, proizvodstvennyi travmatizm (po otdel'nym vidam ekonomicheskoi deyatel'nosti) [Working conditions and occupational injuries (as per specific economic activities)]. Federal'naya sluzhba gosudarstvennoi statistiki, 2019. Available at: http://www.gks.ru/wps/wcm/connect/rosstat_main/rosstat/ru/statistics/wages/working_conditions/ (19.06.2019) (in Russian).

2. Karimova L.K., Kaptsov V.A., Salimgareeva T.M., Mavrina L.N., Gimaeva Z.F., Beigul N.A. Health risk assessment of violations of workers of enterprises of fuel and energy complex. Zdorov'e naseleniya i sreda obitaniya, 2017, vol. 289, no. 4, pp. 25-30 (in Russian).

3. Petrone P., Asensio J.A., Marini C.P. Management of accidental hypothermia and cold injury. Curr. Probl. Surg., 2014, vol. 51, no. 10, pp. 417-431. DOI: 10.1067/j.cpsurg.2014.07.004

4. Romu T., Vavruch C., Dahlqvist-Leinhard O., Tallberg J., Dahlström N., Persson A., Heglind M., Lidell M.E. [et al.]. A randomized trial of cold-exposure on energy expenditure and supraclavicular brown adipose tissue volume in humans. Metabolism, 2016, vol. 65, no. 6, pp. 926-934. DOI: $10.1016 /$ j.metabol.2016.03.012

5. Sarychev A.S., Gudkov A.B., Popova O.N., Ivchenko E.V., Belyaev V.R. The characteristic of kompensatory-adaptive reactions of external respiration at oil industry workers in dynamics expeditionary rotational team work in the Polar region. Vestnik Rossiiskoi voenno-meditsinskoi akademii, 2011, vol. 3, no. 35, pp. 163-166 (in Russian).

6. Maslov L.N., Tsibul'nikov S.Yu., Naryzhnaya N.V., Ivanov V.V, Tsibul'nikova M.R. Chronic exposure to cold is adaptation without stress. Patologicheskaya fiziologiya i eksperimental'naya terapiya, 2016, vol. 60, no. 1, pp. 28-31 (in Russian).

7. Ingram B.J., Raymond T.J. Recognition and treatment of freezing and nonfreezing cold injuries. Curr. Sports. Med. Rep., 2013, vol. 12, no. 2, pp. 125-130. DOI: 10.1249/JSR.0b013e3182877454

8. Gudkov A.B., Popova O.N. Vneshnee dykhanie cheloveka na Evropeiskom Severe [External respiration in European Northern regions]. Arkhangel'sk, Izdatel'stvo Severnogo gosudarstvennogo meditsinskogo universiteta Publ., 2009, 242 p. (in Russian)

9. Bashkireva A.S., Artamonova V.G., Khavinson V.Kh. Productive aging or «healthy worker effect»? Retrospective analysis of morbidity with temporal workability loss in motor transport drivers. Uspekhi Gerontologii, 2009, vol. 22, no. 4, pp. 539-547 (in Russian).

10. Maksimov S.A. Healthy worker effect in epidemiological researches. Meditsina $v$ Kuzbasse, 2015, vol. 14, no. 2, pp. 10-15 (in Russian).

11. Ageev F.T., Smirnova M.D., Svirida O.N., Fofanova T.V., Vitsenya M.V., Blankova Z.N., Mikhailov G.V., Lankin V.Z. [et al.]. Impact of a cold wave on disease course, hemodynamics, carbohydrate metabolism, and blood rheological properties in cardiac patents. Terapevticheskii arkhiv, 2015, vol. 87, no. 9, pp. 11-16 (in Russian).

12. Nagibovich O.A., Ukhovsky D.M., Zhekalov A.N., Tkachuk N.A., Arzhavkina L.G., Bogdanova E.G., Murzina E.V., Belikova T.M. Mechanisms of hypoxia in Arctic zone of Russian Federation. Vestnik rossiiskoi voenno-meditsinskoi akademii, 2016, no. 2 (54), pp. 202-205 (in Russian).

13. Maslov L.N., Vychuzhanova E.A. Influence of long-term adaptation to cold on the state of cardiovascular system. Rossiiskii fiziologicheskii zhurnal im. I.M. Sechenova, 2013, vol. 99, no. 10, pp. 1113-1124 (in Russian). 
14. Kim F., Nichol G., Maynard C., Hallstrom A., Kudenchuk P.G., Rea T., Copas M.C., Carlbom D. [et al.]. Effect of Prehospital Induction of Mild Hypothermia on Survival and Neurological Status among Adults with Cardiac Arrest: A Randomized Clinical Trial. JAMA, 2014, vol. 311, no. 1 , pp. 45-52. DOI: 10.1001/jama.2013.282173

15. Konduktivnaya poterya slukha: kakoe lechenie naznachayut pri tugoukhosti 1 stepeni [Conduction hearing loss: how to treat primary hearing loss]. Lechenie zabolevanii ukha, gorla, nosa, 2019. Available at: https://prolor.ru/u/bolezni/tugouxost/konduktivnaya.html (16.10.2019) (in Russian).

16. Sitnikov V.P., El'-Refai Kh. Modern aspects of surgical treatment of patients with chronic suppurative otitis media. Problemy zdorov'ya i ekologii, 2010, vol. 24, no. 2, pp. 37-41 (in Russian).

17. Chashchin V.P., Syurin S.A., Gudkov A.B., Popova O.N., Voronin A.Yu. Influence of industrial pollution of ambient air on health of workers engaged into open air activities in cold conditions. Meditsina truda i promyshlennaya ekologiya, 2014, no. 9, pp. 20-26 (in Russian).

18. Chashchin V.P., Gudkov A.B., Chashchin M.V., Popova O.N. Predictive assessment of individual human susceptibility to damaging cold exposure. Ekologiya cheloveka, 2017, no. 5, pp. 3-13 (in Russian).

19. Jurkovich G.J. Environmental cold-induced injury. Surg Clin North Am, 2007, vol. 87, no. 1, pp. $247-267$.

20. Revich B., Shaposhnikov D. Temperature-induced excess mortality in Moscow. International Journal Biometeorology, 2008, no. 52, pp. 367-374.

Polyakova E.M., Mel'tser A.V., Chashchin V.P. Risk factors causing health disorders among workers involved in oil extraction and performing their working tasks outdoors during a cold season. Health Risk Analysis, 2019, no. 4, pp. 84-92. DOI: 10.21668/health.risk/2019.4.09.eng

Received: 31.10 .2019

Accepted: 01.12.2019

Published: 30.12.2019 